\title{
Network Technologies for Solving Tasks \\ of Providing Geodynamic Safety \\ of Urban Territory by the Example \\ of the City of Krasnoyarsk
}

\author{
Aleksey A. Kabanov, \\ Mikhail A. Kurako*, Sergey A. Peretokin, \\ Konstantin V. Simonov and Michail V. Golg \\ Siberian Federal University \\ 79 Svobodny, 660041, Krasnoyarsk, Russia \\ Institute of Computational Modeling SB RAS \\ 50/44 Academgorodok, 660036, Krasnoyarsk, Russia
}

Received 02.10.2017, received in revised form 20.10.2017, accepted 06.11.2017

The research is focused on the development of computer applications, designed on the single algorithmic platform to processing large amounts of geomonitoring data, assessing geodynamic hazards and aimed at providing geodynamic safety of urban territory in the frame of the concept "Smart City" by the example of the city of Krasnoyarsk. The innovative solutions suggested by the research conform to modern network technologies relating to distributed land cadastral registries as well as to the insurance of correspondent risks and other tasks of digital economy. The research has been conducted within the scope of the grant "Methodical approaches for development of a concept of designing project "Smart City in the context of digital economy development trends" with the financial support from the Krasnoyarsk Regional Fund of Support of Scientific and Technical Activities.

Keywords: big data, computer platform, distributed technologies, digital economy.

Citation: Kabanov A.A., Kurako M.A., Peretokin S.A., Simonov K.V., Gold M.V. Network technologies for solving tasks of providing geodynamic safety of urban territory by the example of the city of Krasnoyarsk, J. Sib. Fed. Univ. Eng. technol., 2018, 11(1), 102-115. DOI: 10.17516/1999-494X-0014.

(C) Siberian Federal University. All rights reserved

* Corresponding author E-mail address: mkurako@sfu-kras.ru 


\title{
Сетевые технологии решения задач
}

\section{обеспечения геодинамической безопасности \\ урбанизированной территории}

на примере г. Красноярска

\author{
А.А. Кабанов, М.А. Курако, \\ С.А. Перетокин, К.В. Симонов, М.В. Гольд \\ Сибирский федеральный университет \\ Россия, 660041, Красноярск, пр. Свободный, 79 \\ Институт вычислительного моделирования СО РАН \\ Россия, 660036, Красноярск, Академгородок, 50/44
}

Исследование посвящено разработке компьютерных приложений, создаваемых на единой алгоритмической платформе для обработки большихмассивов данныхгеомониторинга, оиенки геодинамической опасности и направлено на обеспечение геодинамической безопасности урбанизированной территории в рамках концепции «умный город» на примере г. Красноярска. Инновачионные решения, предлагаемые в исследовании, соответствуют современным сетевым технологиях применительно к распределённым земельным кадастровым реестрам, а также страхованию соответствующих рисков и другим задачам ичифровой экономики. Исследование выполнено в рамках гранта «Методические подходы к формированию концепиии создания проекта «Умный город (Smart City)» в контексте трендов развития цифрровой экономики» при финансовой поддержке Красноярского краевого фонда поддержки научной и научно-технической деятельности.

Ключевые слова: большие данные, компьютерная платформа, распределённые технологии, цифровая экономика.

\section{Введение}

Усиление в последние годы сейсмической активности очаговых зон сильных землетрясений Алтае-Саянской сейсмоактивной области (АССО), представляющих реальную опасность для южной и центральной части Красноярского края, вызвало необходимость создания эффективной системы геомониторинга на территории региона. В свою очередь создание сейсмологической сети на территории края и начало сейсмомониторинга повлекло за собой необходимость детальных неотектонических и сейсмогеологических исследований для решения актуальных задач оценки геодинамической опасности. Значительные научные достижения в рамках долгосрочной оценки сейсмической опасности (разработка карт общего сейсмического районирования, ОСР-2016) только подчёркивают актуальность решения проблемы краткосрочной оценки сейсмической опасности [1].

В настоящее время в методологическом отношении признан приоритет методов среднесрочной оценки сейсмической опасности (месяцы, до 1-2 лет), которые, по экспертным оценкам, могут предсказывать до 80 \% сильных землетрясений, но с некоторой неопределённостью по территориальной привязке. Для обеспечения геодинамической и геоэкологической безопасности, жизнедеятельности населения и техногенных объектов промышленных агломераций региона, плотин и водохранилищ крупных ГЭС, необходимо осуществлять 
непрерывные сейсмические и геодинамические наблюдения с использованием как региональной сети сейсмических станций, так и системы локальных сетей геодинамического мониторинга [2] .

Широкое использование локальных сейсмических сетей обуславливается их высокой чувствительностью к сейсмодеформационным процессам в земной коре, высокоточным определением координат эпицентров и глубин очагов землетрясений, возможностью картирования потенциальных очагов активизации и одновременно объёмного (сейсмотомографического) моделирования геосреды по скоростным и энергетическим характеристикам сейсмических волн. Обеспечивая важную фактическую информацию о пространственно-временном поведении слабых землетрясений, локальная сейсмическая сеть становится незаменимым инструментом при оценке геодинамической опасности [3].

Таким образом, информационной основой обеспечения геодинамической безопасности исследуемого региона и территорий крупных промышленных агломераций являются результаты решения основных задач геомониторинга очаговых областей сильных землетрясений АССО. В этой связи, важной является разработка новых методических подходов при организации сети регионального мониторинга естественных геофизических полей в рамках полигонных исследований на территории АССО. При этом основной задачей является разработка аппаратурного и методического обеспечения, а также алгоритмического обеспечения специализированной платформы обработки и анализа больших массивов данных для контроля очаговой зоны подготовки сильного землетрясения и анализа низкоэнергетической составляющей сейсмического режима изучаемой территории [4-7].

В настоящее время созданы основы информационного, методического и алгоритмического обеспечения для точной и своевременной оценки параметров ожидаемого события для выделенной очаговой области в рамках сетевой технологии решения проблемы обеспечения геодинамической и геоэкологической безопасности территории промышленных агломераций региона, включающих плотины и водохранилища крупных ГЭС.

Целью исследований является повышение точности и своевременности оценки параметров ожидаемого землетрясения для оперативного решения задач геодинамической и геоэкологической опасности. Разработаны алгоритмы выделения и анализа предвестников сильных землетрясений для решения задачи оперативной оценки параметров ожидаемого сильного землетрясения. На этой основе построены карты-схемы детального районирования территории г. Красноярска по степени геодинамической и геоэкологической опасности. Таким образом, предлагается реализация комплексного подхода к решению научных, социальных и управленческих задач по обеспечению геодинамической безопасности территории г. Красноярска на принципах сетевого геодинамического контроля геосреды.

\section{1. Сетевые технологии решения задачи оперативной оценки геодинамической опасности}

Южные районы Центральной Сибири, в которых сосредоточено более 200 промышленных объектов высокой степени экологической опасности, включая крупные ГЭС и ТЭЦ, характеризуются сейсмичностью согласно ОСР-97 от 5-6 до 7-8 баллов для объектов общегражданского назначения и соответственно 6-7 и 8-9 баллов для особо опасных объектов. 


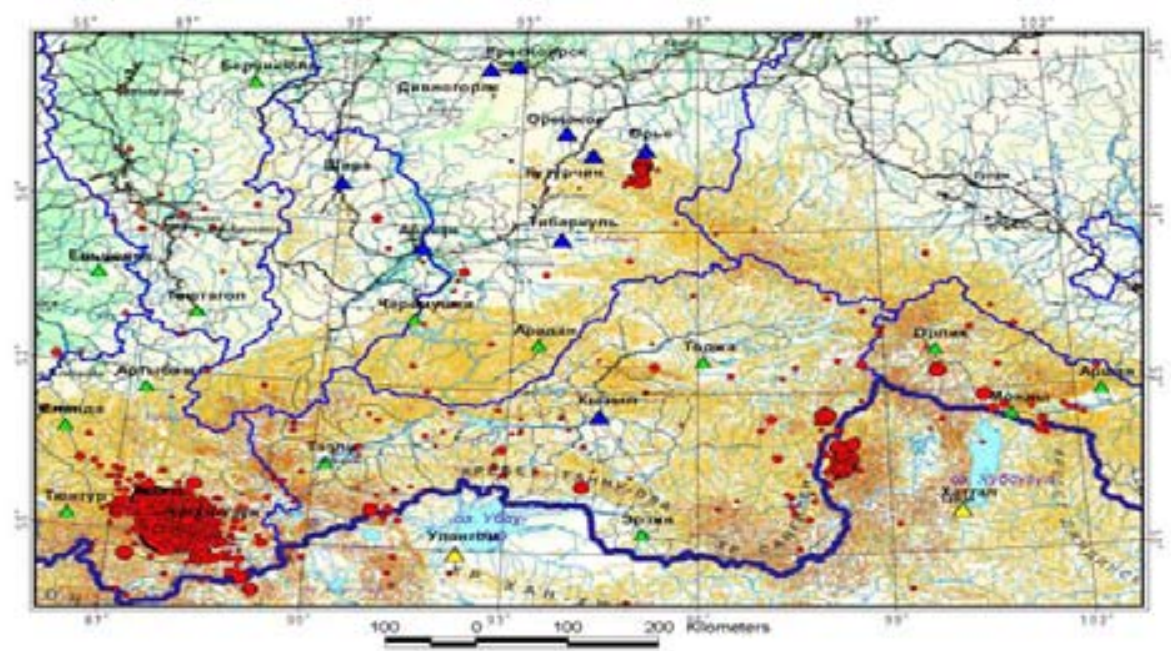

Рис. 1. Расположение сейсмостанций и зарегистрированные с их участием землетрясения

Fig. 1. Location of seismic stations and recorded earthquakes

Геодинамические угрозы для территории Красноярского края исходят от следующих типов неблагоприятных геодинамических факторов сейсмической природы различного масштаба (рис. 1) [8-10].

Глобальные сейсмогеологические катастрофы, обусловленные сильнейшими землетрясениями в районах Горного Алтая и Монголии, р. Тыва (с магнитудой 7,5-8,5 по шкале Рихтера) вызовут сотрясаемость для городов Красноярской промышленной агломерации до 4-6 баллов по шкале МСК-64. Алтайское землетрясение 27 сентября 2003 г., Каа-Хемские землетрясения 27 декабря 2011 г. и 26 февраля 2012 г. подтверждают реальность этой угрозы и высокую вероятность существенных геоэкологических и техногенных последствий - сход значительных оползней на территории городов и разрушение элементов их инфраструктуры.

Региональные сильные землетрясения (с магнитудой 5,5-7,0 по шкале Рихтера), обусловленные сейсмогеологической жизнью крупнейших тектонических разломов, расположенных на территории края, вызовут сотрясаемость на территории городов Красноярского края около 5-6 баллов по шкале МСК-64. Караганские землетрясения 27 октября 2000 г. и 8 мая 2004 г. (Саянский район), землетрясение 10 февраля 2011 г. (Ермаковский район) являются типичными представителями сейсмических событий этого класса. При возникновении аналогичного землетрясения в 50-70 километровой зоне вблизи г. Красноярска ущерб будет достаточно серьёзен, вследствие повышенной природно-техногенной уязвимости территории городов Красноярской промышленной агломерации (Дивногорск, Красноярск, Железногорск).

Местные сильные сейсмические события (с магнитудой 3,5-4,5 по шкале Рихтера), приуроченные к локальным разломным тектоническим зонам на территории края вызовут сотрясаемость для городов Красноярского края на уровне 4-6 баллов по шкале МСК-64, поскольку эпицентральные зоны в этом случае непосредственно охватывают населённые пункты. Синеборское землетрясение 24 января 2003 г. (Шушенский район), Крольское землетрясение 
24 марта 2009 г. (Курагинский район) представляют собой модель указанного типа сейсмического события.

Следует отметить, что Караганское землетрясение 27 октября 2000 г. с интенсивностью 7-7,5 баллов в плейстосейстовой области и эпицентром в 180 км от г. Красноярска и проявления Алтайского землетрясения 27 сентября 2003 г. выявили существенные недостатки в обеспечении геодинамической безопасности региона. Сейсмические сети Геофизической службы (ГС) СО РАН и других ведомств (Минатома, Минтопэнерго) по своим параметрам (плотности, оперативности передачи данных) не позволяют решать задачи, связанные со средне- и краткосрочными оценками параметров землетрясений в регионе. Существующие сейсмические службы Российской Федерации ГС РАН (г. Обнинск) и ГС СО РАН (г. Новосибирск) не имеют возможности оперативно и уверенно оценивать параметры региональных и местных сейсмических событий вследствие крайне малого числа сейсмических станций на территории края (сейсмические станции «Черёмушки» и «Мина»), которые регистрируют, в основном, только глобальные события.

Проведён анализ существующих систем геомониторинга для изучения геодинамической обстановки исследуемой территории Алтае-Саянской сейсмоактивной области, а также методов обработки данных геодинамического мониторинга очаговых зон. Показано, что существующие традиционные системы геомониторинга и алгоритмическое обеспечение не позволяют решать задачи оценки геодинамической опасности, а также экспертной оценки балла сотрясаемости от ожидаемых сильных землетрясений в регионе.

Предложено и обосновано приборное, методическое и информационное обеспечение пунктов геомониторинга в рамках полигонных исследований естественных геофизических полей для контроля процесса подготовки сильного землетрясения. Разработанная сетевая схема геодинамического мониторинга обеспечивает регистрацию геодинамических процессов на всей территории исследуемой области рациональностью размещения режимных пунктов с минимальным уровнем микросейсмического фона, что позволяет регистрировать землетрясения с низкой магнитудой (рис. 2).

Предложенные параметры информационной системы геодинамического мониторинга и разработанное алгоритмическое и методическое обеспечение для пунктов наблюдений естественных геофизических полей позволили в 2009-2017 гг. выделить предвестники-структуры в процессе подготовки сильных землетрясений на территории Алтае-Саянской сейсмоактивной области (рис. 3). Практика регистрации сильнейших землетрясений в регионе в 2009-2017 гг. показывает эффективность созданной системы геомониторинга на описанных выше принципах сетевой организации решения указанной первой задачи.

\section{2. Сетевые технологии для построения карты-схемы (модели) детального районирования территории г. Красноярска}

Цель исследований в этой части состоит в разработке методики оценки геодинамической и геоэкологической опасности применительно к территории Красноярской промышленной агломерации в рамках методологии составления и уточнения карт ОСР-97 [11-13]. В результате проведённых исследований уточнена модель зон ВОЗ для территории Красноярской агломерации. В соответствии с технологией построения карт ОСР-97 рассчитаны уточнённые значения 


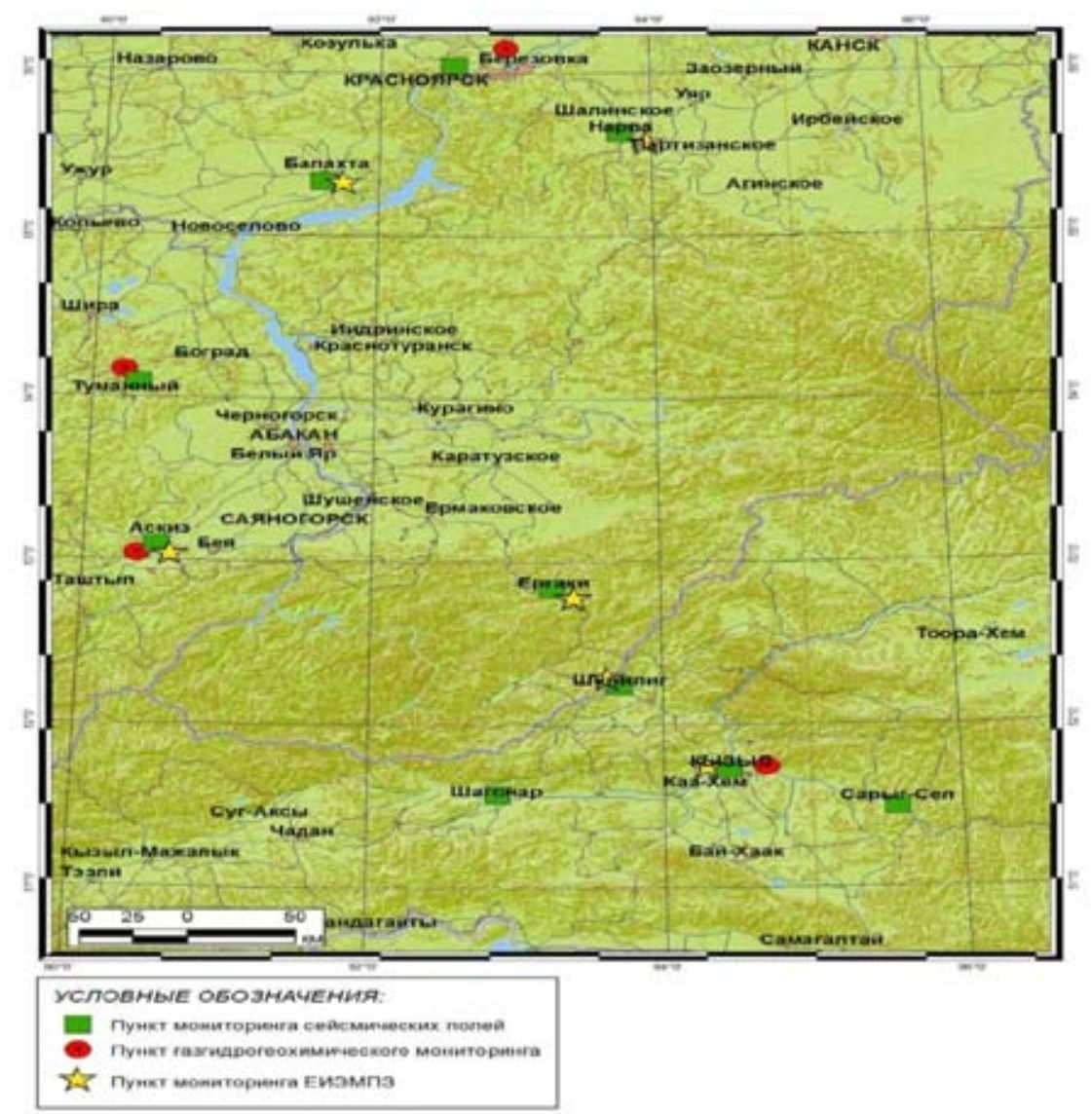

Рис. 2. Схема сети геофизического и газгидрогеохимического мониторинга на Алтае-Саянском полигоне (условные обозначения: пункт мониторинга сейсмических полей; пункт газгидрогеохического мониторинга; пункт мониторинга ЕИЭМПЗ)

Fig. 2. Scheme of a network of geophysical and gas hydrogeochemical monitoring in the Altai-Sayan range (conventional symbols: point of monitoring of seismic fields; point of gas hydrogeochemical monitoring; point of monitoring of the natural pulsed electromagnetic field of the Earth)

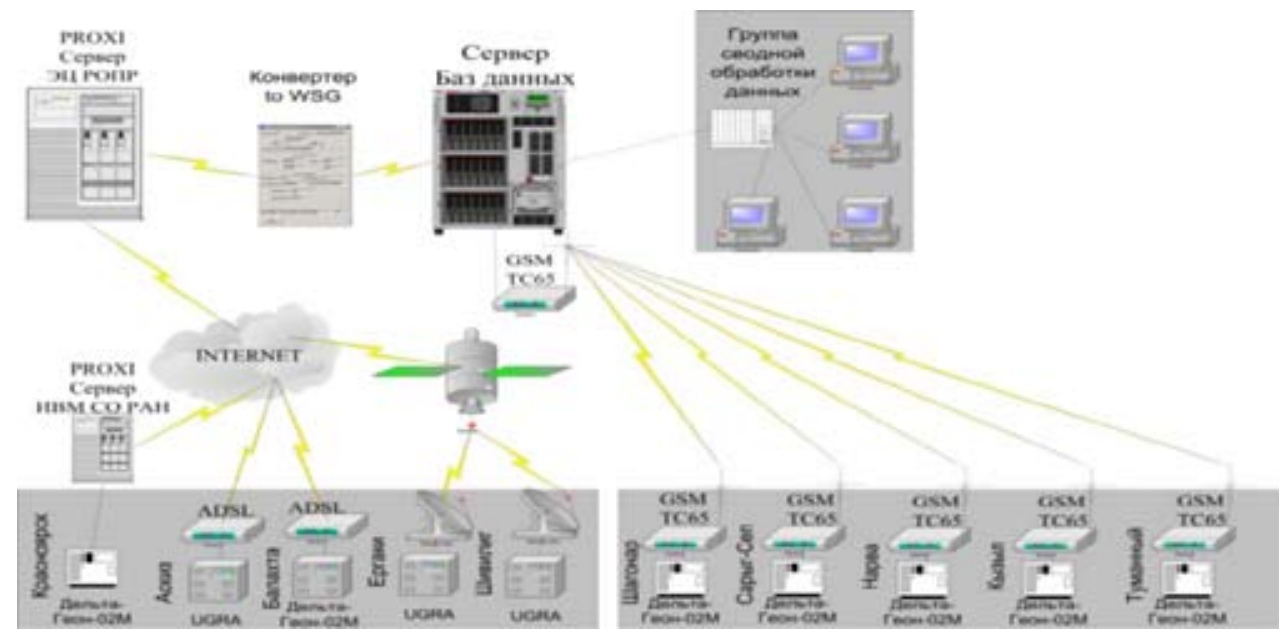

Рис. 3. Структурная схема сбора и обработки данных геомониторинга

Fig. 3. Block diagram of the data collection and processing of geomonitoring 


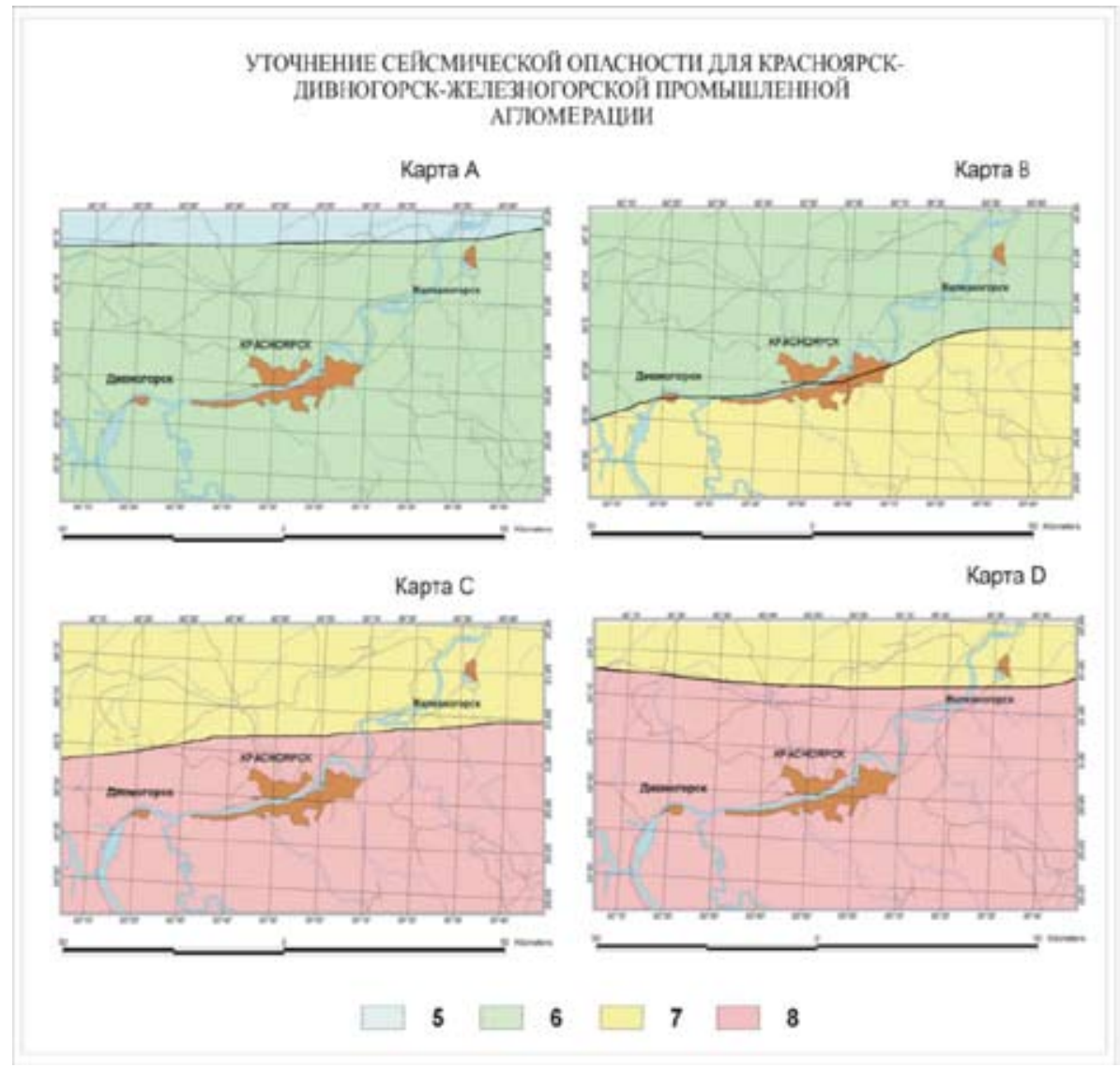

Рис. 4. Уточнение геодинамической опасности для Красноярской промышленной агломерации (уточнение сейсмической опасности для Красноярск-Дивногорск-Железногорской промышленной агломерации: карта A, карта B, карта C, карта D)

Fig. 4. Clarification of geodynamic hazards for the Krasnoyarsk industrial agglomeration (clarification of the seismic hazard for the Krasnoyarsk-Divnogorsk-Zheleznogorsk industrial agglomeration: map A, map B, map C, map D)

балльности для изучаемой территории (рис. 4). Для достижения указанного результата и его обоснования проведены следующие исследования:

- создана дополнительная сеть сейсмических станций для проведения сейсмического мониторинга в районе Красноярской промышленной агломерации и прилегающих территорий;

- произведён (производится и в настоящий момент) сбор сведений о слабой сейсмичности в трёхсоткилометровой зоне вокруг Красноярской агломерации;

- выполнен комплекс работ по выявлению палеосейсмодислокаций в районе исследований, в частности, выявлена Малиновская палеосейсмодислокация;

- детально изучены современные тектонические движения геологической среды;

- проведён анализ сейсмичности исследуемой территории по унифицированным каталогам землетрясений с учётом новых данных сейсмического мониторинга; 
- выполнена корректировка параметров зон возникновения очагов землетрясений, использовавшихся в модели зон ВОЗ при расчёте карт ОСР-97, с учётом разломно-блоковой структуры среды и особенностей её сейсмического режима;

- для рассматриваемой территории рассчитан комплект карт уточнения сейсмической опасности (УСО), отражающих вероятность возможного превышения конкретных величин сейсмических воздействий в течение заданных интервалов времени.

В итоге, составлены таблицы с параметризацией основных структурных элементов (зон) и комплект карт УСО, характеризующих уровень сейсмической опасности в соответствии с ОСР-97. Исследования по анализу комплекса сейсмологических данных являются основой для проведения расчётов и моделирования сейсмичского режима в рамках вычислительной технологии ОСР-97.

На основе систематизации и обобщения специализированной информации разработана новая карта-схема (модель) детального районирования территории г. Красноярска и выполнены оценки комплекса показателей геодинамической и геоэкологической опасности. Представлены результаты проведённых исследований и приведены оценки геодинамической опасности г. Красноярска и прилегающей территории по трём методам: экспертная оценка с учётом геодинамических и геоэкологических факторов; на основе расчёта приращения балльности относительно эталонного грунта с помощью сейсморазведки методом акустической жёсткости; расчётов сотрясаемости грунта в рамках технологии ОСР-97.

Выполненное с помощью предложенных подходов районирование геодинамической и геоэкологической опасности является основанием для планирования мероприятий по обеспечению геодинамической и геоэкологической безопасности территории г. Красноярска, насыщенной промышленными техногенными объектами особой важности. Карты общего сейсмического районирования демонстрируют оценку возможной максимальной сотрясаемости для заданного интервала времени: ОСР-97-А - период повторяемости 1 раз в 500 лет; ОСР-97-В период повторяемости 1 раз в 1000 лет. Согласно карте ОСР-97-А для общегражданского строительства, территория г. Красноярска находится в 6-ти бальной зоне сотрясаемости.

Расчёт прогнозной интенсивности сотрясаемости осуществляется путём подсчёта суммы экспертных оценок по трём разделам (макросейсмическому, инструментальному и геодинамическому). Окончательная прогнозная оценка даётся по максимальному числу экспертных оценок, набранных либо по сейсмологическим факторам, либо по сумме геодинамических факторов. Исходный балл принят за 2 и ему придана экспертная оценка 20. Последующие экспертные оценки образуются путём умножения исходной экспертной оценки на число баллов. При этом сумма экспертных оценок, подобранная для всех остальных геодинамических показателей, не превышает 40 ед., т.е. 2-х баллов. Именно на такую максимальную величину может быть увеличен исходный сейсмический потенциал, определяемый по факторам геодинамической активности литосферы и её геодинамическому режиму.

Для получения экспертных оценок территория г. Красноярска была разбита на 247 квадратов, каждому из которых присвоен индивидуальный номер. В каждом квадрате оценивались геодинамическая активность, прочность слагающих территорию горных пород, тектоническая деструкция, структура вертикального разреза, обводненность пород, экзогенные процессы (рис. 5).

$$
-109-
$$




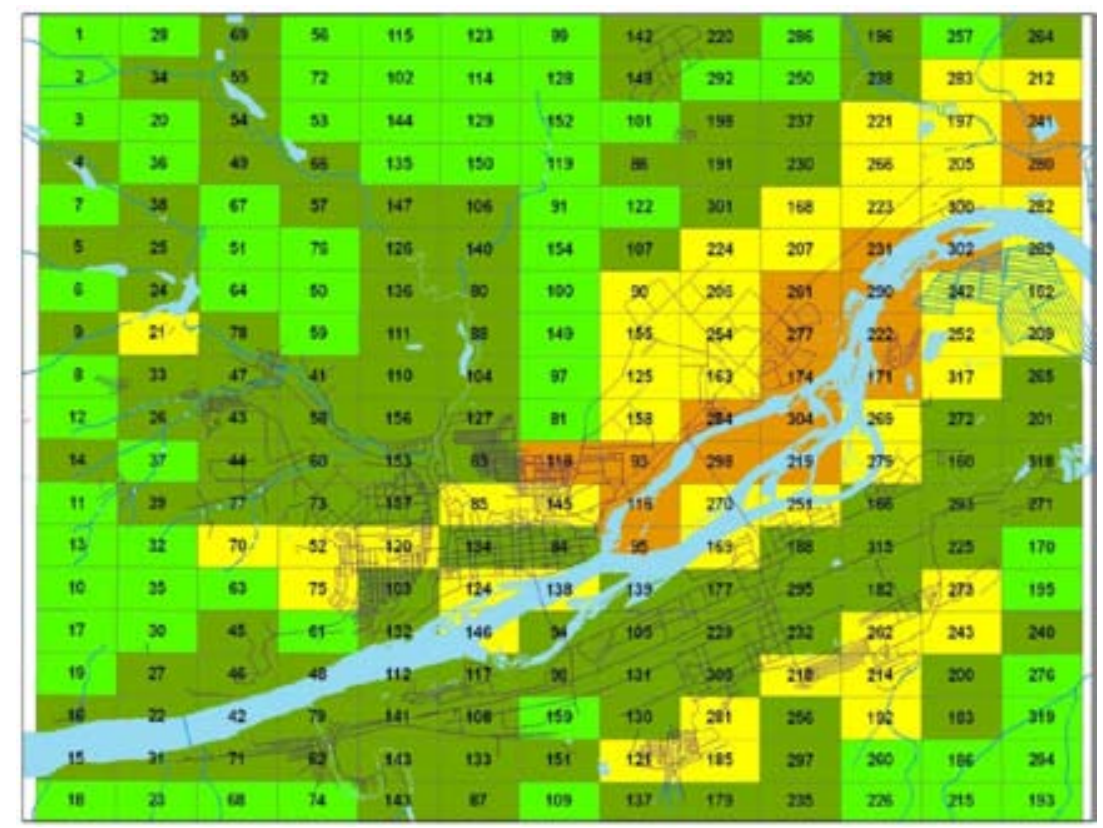

Рис. 5. Схема районирования территории г. Красноярска и его окрестностей на основе экспертной оценки геодинамических факторов

Fig. 5. Scheme of regionalization of the territory of Krasnoyarsk based on an expert assessment of geodynamic factors

Метод сейсмических жёсткостей применяется для оценки относительных изменений (приращений) сейсмической балльности при сейсмическом микрорайонировании. Оценка приращения балльности и расчёт параметров сейсмических воздействий осуществляются путём сравнения отношений сейсмических (акустических) жёсткостей, представляющих произведение скорости распространения сейсмических волн на средние значения плотности грунта для изучаемого и эталонного разреза. Для количественной оценки скоростей сейсмических волн и последующего расчёта по методу акустических жестокостей реакции сейсмореализующего слоя на вероятные сильные землетрясения проведены инструментальные сейсмические исследования (рис. 6).

На основе использования электронной базы данных ОСР-97 рассчитана исходная (фоновая) сейсмическая интенсивность г. Красноярска в баллах шкалы MSK-64 с периодом повторения 500 лет, т.е. восстанавливалась карта ОСР-97-А - для массового строительства жилых, общественных и производственных зданий.

Численное моделирование реакции геологической среды на сильные землетрясения осуществлялось по программе NERA, представляющей модифицированный алгоритм программы SHAKE-91. В основу расчёта положено определяющее влияние на сейсмические свойства грунтов следующих факторов: скорости распространения продольных и поперечных волн в различных грунтовых комплексах, плотностные характеристики грунтов в естественном залегании; состав и мощность толщи рыхлых (четвертичных) отложений; состав и степень сохранности пород коренной основы, принимаемых при дальнейших расчётах за упругое полупространство (рис. 7). 


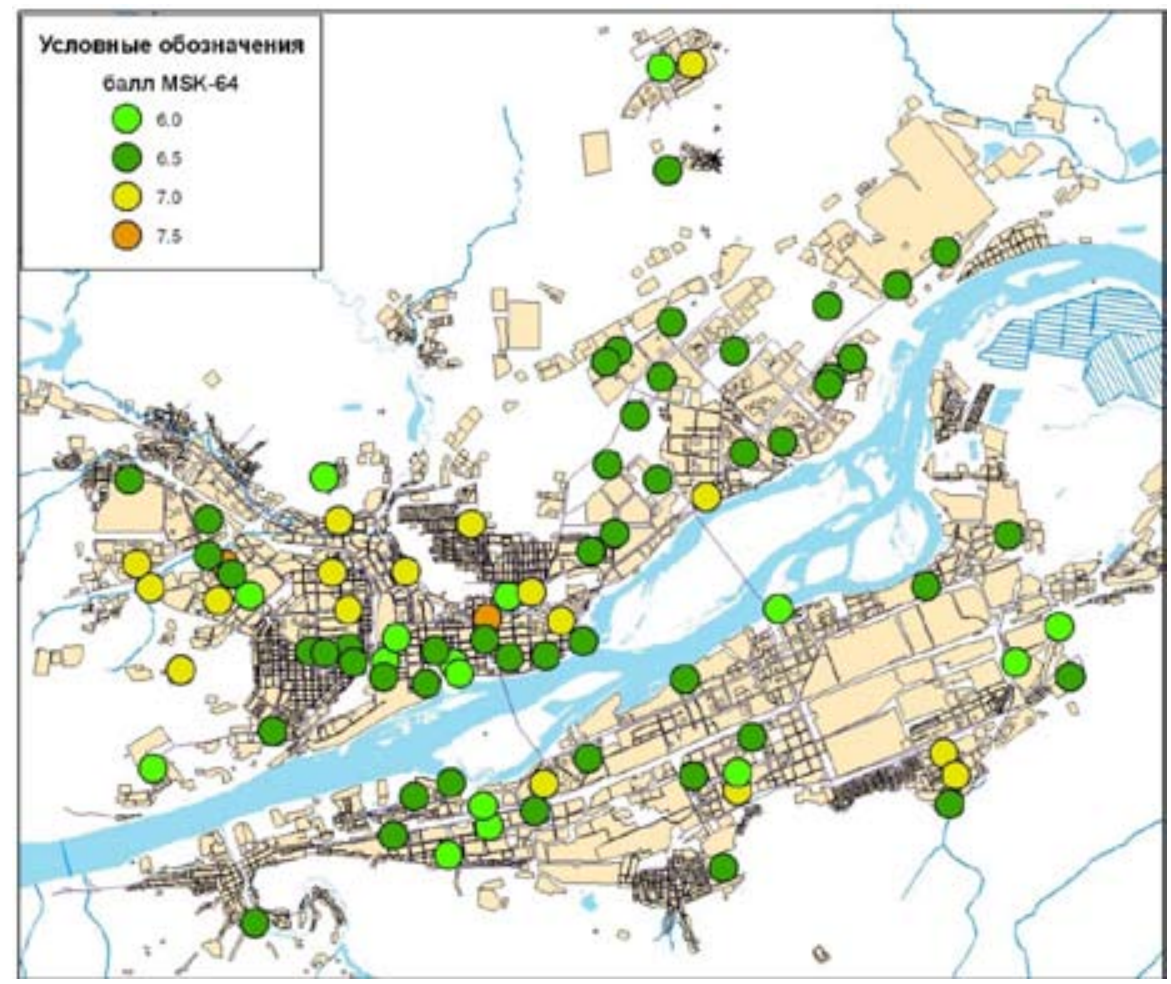

Рис. 6. Результаты расчётов сотрясаемости различных участков территории г. Красноярска методом акустических жёсткостей

Fig. 6. Results of calculations of the shock of various sections of the territory of Krasnoyarsk by the method of acoustic stiffnesses (conventional symbols: points on the score MSK-64)

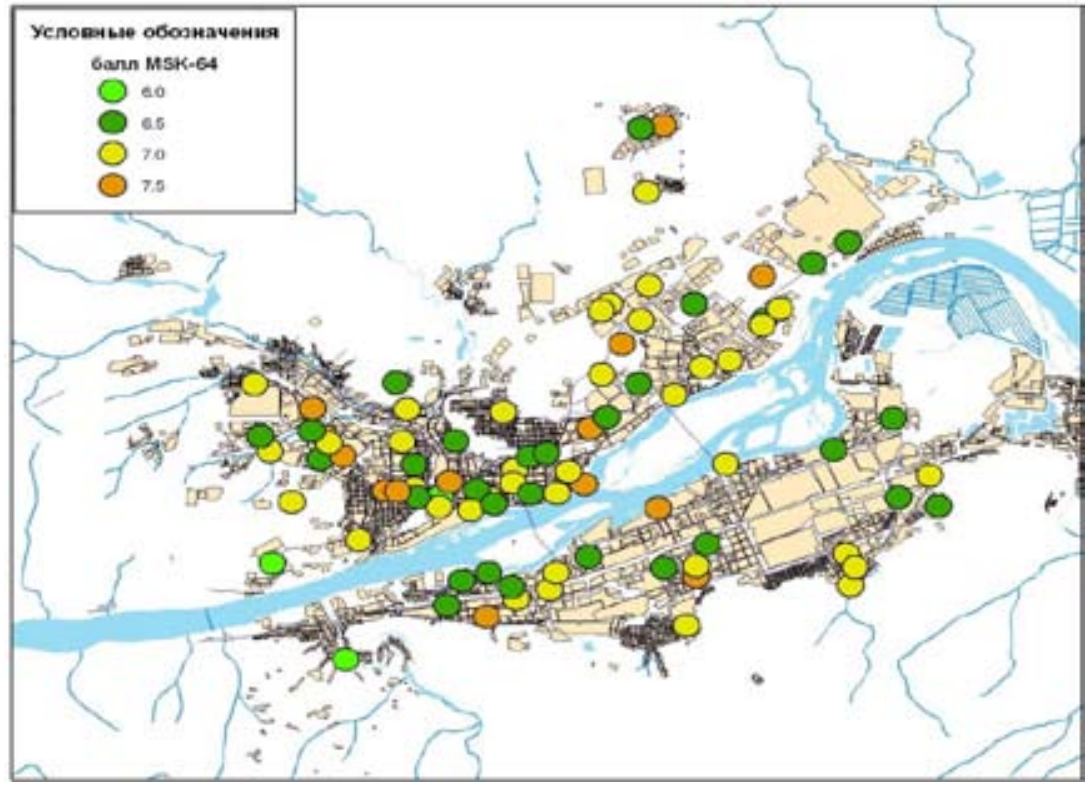

Рис. 7. Результаты расчётов сотрясаемости

Fig. 7. Results of shock calculations (conventional symbols: points on the score MSK-64) 


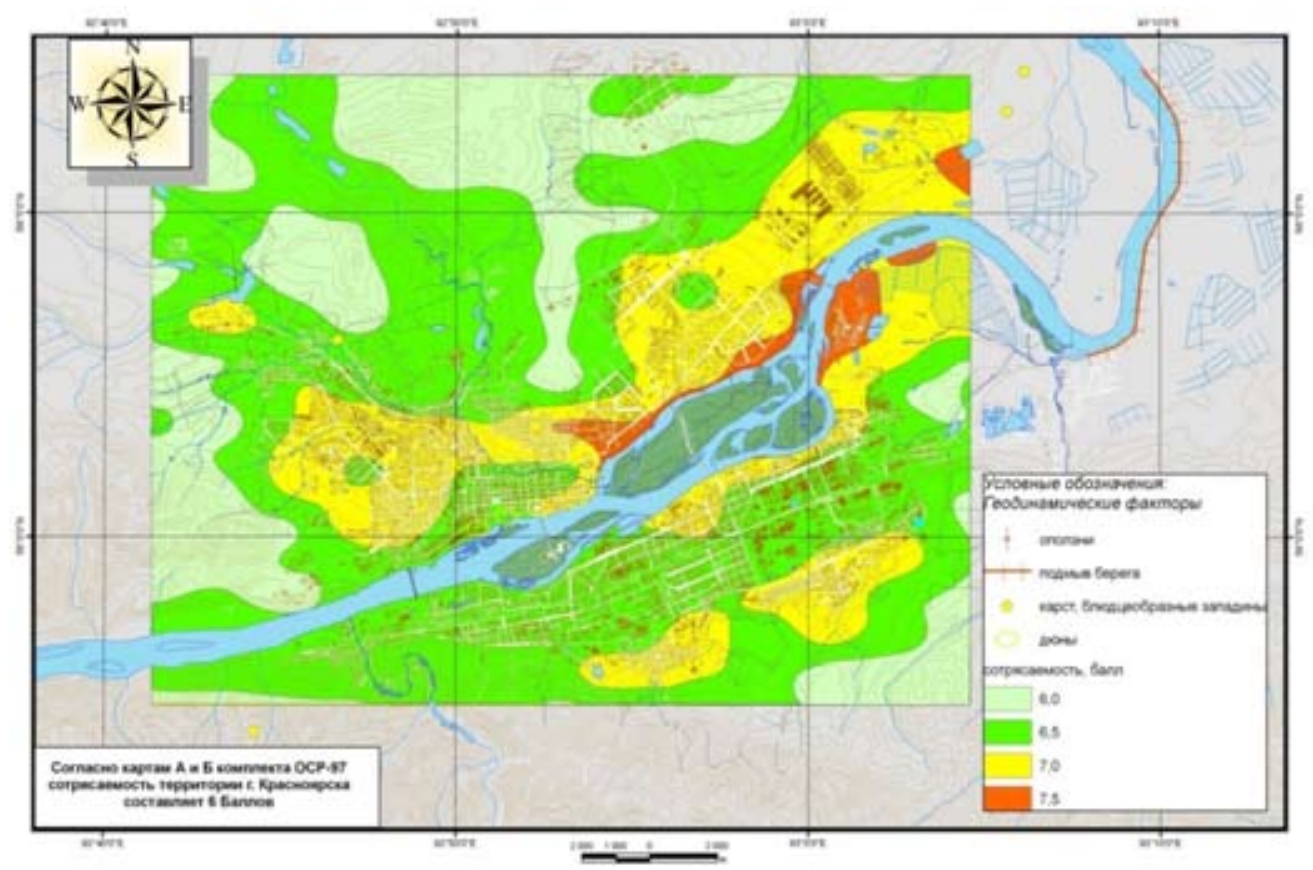

Рис. 8. Схема-модель районирования территории г. Красноярска на основе учёта изучаемых факторов. Согласно картам А и Б комплекта карт общего сейсмического районирования ОСР-97 сотрясаемость территории г. Красноярска составляет 6 баллов (условные обозначения: геодинамические факторы оползни, размыв берега, карст, дюны; сотрясаемость - в баллах по шкале MSK-64)

Fig. 8. Scheme-model of the regionalization of the territory of Krasnoyarsk based on the account of all studied factors. According to maps A and B of the map of the general seismic zoning of the OSR-97, the terrain of the city of Krasnoyarsk is 6 points (symbols: geodynamic factors - landslides, shore erosion, karst, dunes, shaking - points on the score MSK-64)

В итоге, представлены: экспертная оценка с учётом геодинамических факторов; оценка на основе расчёта приращения балльности относительно эталонного грунта с помощью сейсморазведки методом акустической жёсткости; расчёта сотрясаемости грунта в рамках технологии ОСР-97.

Далее выполнено обобщение указанных оценок с помощью алгоритма, где реализован метод скользящего окна. Выбиралась ячейка экспертной оценки, если в неё входили одна или более оценок другими соответствующими вышеописанными методами, то ей присваивалось новое значение сотрясаемости. В результате выполнения указанной вычислительной процедуры получена карта-схема сейсмического районирования территории г. Красноярска. Следующим шагом выполнено интерполирование полученной ячеистой карты-схемы регуляризированным сплайном. Итог - новая схема-модель районирования территории г. Красноярска и прилегающих территорий (рис. 8).

В рамках исследования также описан подход к решению управленческих задач по обеспечению геодинамической безопасности территории г. Красноярска на принципах «сетевого геодинамического контроля геосреды». Разработаны элементы информационной системы, основанные на принципах распределённого сетевого геодинамического контроля территории г. Красноярска. 


\section{Заключение}

Разработаны и обоснованы новые элементы в составе, конфигурации и взаимодействии в аппаратурном, методическом и информационном обеспечении системы геодинамического мониторинга для повышения эффективности и оптимальности полигонных исследований очаговых зон сильных землетрясений.

Предложенные параметры информационной системы геодинамического мониторинга и разработанное методическое обеспечение для пунктов наблюдений естественных геофизических полей позволили в 2009-2017 гг. выделять предвестники-структуры в процессе подготовки сильных землетрясений на территории Алтае-Саянской сейсмоактивной области.

В результате проведённых исследований систематизирована и обобщена специализированная информация, произведено уточнение и обоснование оценки потенциальной геодинамической опасности для территории г. Красноярска. Выполненное с помощью предложенных подходов районирование геодинамической и геоэкологической опасности является основанием для планирования мероприятий по обеспечению геодинамической и геоэкологической безопасности территории г. Красноярска.

\section{Список литературы}

[1] Сибгатулин В.Г., Перетокин С.А., Худобердин И.Р., Кабанов А.А., Симонов К.В. Оперативные оценки геодинамической опасности Алтае-Саянского региона (2009-2016 гг.). Решетневские чтения: материаль ХХ Юбилейной междунар. науч.-практ. конф., посвящ. памяти генерального конструктора ракетно-космических систем академика М.Ф. Решетнева: в 2 ч. под общ. ред. Ю.Ю. Логинова; Сиб. гос. аэрокосмич. ун-т. Красноярск, 2016. Ч. 1. С. 379381. [Siggatulin V.G., Peretokin S.A., Khudoberdin I.R., Kabanov A.A., Simonov K.V. Operative assessments of the geodynamic hazard of the Altai-Sayan region (2009-2016). Reshetnev readings: Proceedings of the XX Jubilee International. scientific-practical. conf., dedicated. memory of the general designer of rocket-space systems academician M.F. Reshetnev: at 2 parts / under the total. Ed. Yu. Yu. Loginova; Sib. state. aerospace university. Krasnoyarsk, 2016. Part 1. P. 379-381. (in Russian)]

[2] Симонов К.В., Кабанов А.А., Бурцев А.А., Денисенко А.В. Информационное обеспечение геомониторинга территории водохранилищ крупных ГЭС. Информатизация и связь. 2013, 2, 104-106. [Simonov K.V., Kabanov A.A., Burtsev A.A., Denisenko A.V. Information support of geomonitoring of the territory of reservoirs of large hydro power plants. Informatization and Communication. 2013. No. 2. P. 104-106. (in Russian)]

[3] Кабанов А.А., Перетокин С.А., Сибгатулин В.Г., Симонов К.В. Методы оперативной оценки сейсмической опасности. V Всероссийская конференция «Безопасность и живучесть технических систем»: материаль и доклады. Красноярск: Сиб. федер. ун-т, 2015. Т. 1. С. $206-$ 211. [Kabanov A.A., Peretokin S.A., Sibgatulin V.G., Simonov K.V. Methods for rapid assessment of seismic hazard. V All-Russian Conference "Safety and Vitality of Technical Systems": Proceedings and reports. Krasnoyarsk: Sib. Feder. Univ., 2015. Vol. 1. P. 206-211. (in Russian)]

[4] Курако М.А., Симонов К.В. Построение аппроксимационных функций по данным наблюдений. Информатизация и Связь. 2014, 2, 73-76. [Kurako M.A., Simonov K.V. Construction of approximation functions from observational data. Informatization and Communication. 2014. No. 2. P. 73-76. (in Russian)] 
[5] Simonov K.V., Kurako M.A. Computer technology for data processing of complex monitoring of natural geoobjects. Совместный выпуск. Вычислительные технологии, том 20. Вестник КАЗНУ им. Аль-Фараби. Серия математика, механика и информатика, 3 (86), часть I. АлматыНовосибирск, 2015, 294-299. [Simonov K.V., Kurako M.A. Computer technology for data processing of complex monitoring of natural geoobjects. Joint issue. Computational technologies, volume 20. Vestnik KAZNU Al-Farabi. Series of mathematics, mechanics and computer science, No. 3 (86), part I. Almaty - Novosibirsk, 2015. P. 294-299.]

[6] Курако М.А., Симонов К.В. Алгоритмы аппроксимации данных специального вида. Информатизация и Связь. 2017, 2, 81-87. [Kurako M.A., Simonov K.V. Algorithms for approximating data of a special type. Informatization and Communication. 2017. No. 2. P. 81-87. (in Russian)]

[7] Simonov K.V., Peretokin S.A., Kabanov A.A. Evaluation of major parameters of expected strong earthquake. Second Sino-Russian Symposium on Earthquake Monitoring and Prediction. China University of Geosciences, Wuhan. 2015, 16. [Simonov K.V., Peretokin S.A., Kabanov A.A. Evaluation of major parameters of expected strong earthquake. Second Sino-Russian Symposium on Earthquake Monitoring and Prediction. China University of Geosciences, Wuhan. 2015. P. 16.]

[8] Кабанов А.А., Сибгатулин В.Г., Симонов К.В. Геодинамические предвестники недавних землетрясений Алтае-Саянской сейсмоактивной области. Материаль научно-практического семинара «Мониторинг, моделирование и прогнозирование опасных природных явлений и чрезвычайных ситуаиий». Железногорск, 2012, 87-91. [Kabanov A.A., Sibgatulin V.G., Simonov K.V. Geodynamic precursors of recent earthquakes in the Altai-Sayan seismically active region. Proceedings of the scientific and practical seminar "Monitoring, modeling and forecasting of dangerous natural phenomena and emergency situations". Zheleznogorsk, 2012. P. 87-91. (in Russian)]

[9] Кабанов А.А., Симонов К.В., Сибгатулин В.Г. Система комплексного геодинамического мониторинга Алтае-Саянской сейсмоактивной области. Материалы ХIII Всероссийской научнопрактической конференции «Проблемь информатизации региона - 2013». Красноярск, 2013, 134-141. [Kabanov A.A., Simonov K.V., Sibgatulin V.G. System of complex geodynamic monitoring of the Altai-Sayan seismically active area. Proceedings of the XIII All-Russian Scientific and Practical Conference "Problems of Informatization of the Region - 2013". Krasnoyarsk, 2013. P. 134-141. (in Russian)]

[10] Кабанов А.А. Казаков И.В., Мацулев А.Н., Симонов К.В. Анализ подтверждаемости прогнозов сильных землетрясений с учётом влияния внешних геофизических факторов. МатериальХIVВсероссийскойнаучно-практическойконференции Проблемыинформатизации региона (ПИР-2015)». Красноярск, 2015, 78-82. [Kabanov A.A., Kazakov I.V., Matsulev A.N., Simonov K.V. Analysis of the confirmability of strong earthquake predictions taking into account the influence of external geophysical factors.. Proceedings of the XIV All-Russian Scientific and Practical Conference "Problems of Informatization of the Region (PIR-2015)". Krasnoyarsk, 2015. P. 78-82. (in Russian)]

[11] Сибгатулин В.Г., Симонов К.В., Перетокин С.А., Кабанов А.А., Коровин А.Л., Краснораменская Т.Г., Худобердин И.Р. Оценка геодинамических рисков для урбанизированной территории. Горный информационно-аналитический бюллетень. Москва: Издательство «Горная книга», 2009, 18, 51-55. [Sibgatulin V.G., Simonov K.V., Peretokin S.A., Kabanov A.A., Korovin A.L., Krasnoramenskaya T.G., Khudoberdin I.R. Assessment of geodynamic risks for an urbanized area. 
Mining Information Analytical Bulletin. Moscow: Publishing House “Mining Book”, 2009. No. 18. P. 51-55. (in Russian)]

[12] Бодякин Е.В., Перетокин С.А., Симонов К.В. Методика проведения сейсмического микрорайонирования площадок с использованием ГИС технологий. Информатизация и Связь. 2015, 2, 80-83. [Bodyakin E.V., Peretokin S.A., Simonov K.V. Methodology of seismic microzoning of sites using GIS technologies. Informatization and Communication. 2015. No. 2. P. 80-83. (in Russian)]

[13] Бодякин Е.В., Перетокин С.А., Симонов К.В. Оценка сейсмической опасности на основе методов СМР. Безопасность и живучесть технических систем: Материаль и доклады. V Всероссийская конференция. Т. 1. Красноярск: СФУ, 2015, 90-96. [Bodyakin E.V., Peretokin S.A., Simonov K.V. Seismic hazard assessment based on SMZ methods. Safety and survivability of technical systems: Proceedings and reports. V All-Russian Conference. Vol. 1. Krasnoyarsk: SFU, 2015. P. 90-96. (in Russian)] 